N. M. Tryschuk, I. V. Kireyev, S. V. Kolisnyk, K. M. Sytnik

National University of Pharmacy

\title{
The effect of benzilic acid derivatives on the pain threshold using the "hot plate" test
}

The search for new highly effective analgesics is a topical issue of modern pharmacology since drugs currently used in clinical practice do not meet the requirements of efficiency and safety.

Aim. To study of the effect of new derivatives of benzilic acid on the pain threshold using the "hot plate" test.

Materials and methods. The objects of the study were new derivatives of benzilic acid. Determination of the pain threshold was carried out by the "hot plate" test. The substances studied were introduced orally as aqueous solutions in the dose of $12 \mathrm{mg} / \mathrm{kg}$. The latent periods of the first licking of the paw sole and the first jump were recorded during the study.

Results. Six- and seven-membered thienolactames did not show the analgesic activity, and acid benzilic amides yielded far exceeded their activity. Hence, formation of cyclic products led to a decrease of the activity. Introduction of the chlorine atom into molecules also led to the decrease of activity. At the same time, the structural modification of the amide group in thienopyrroles was effective. In the experiment the most active substance was KMS-49 containing the dimethylacetyl group. Another active compound was a derivative of KMS-284 belonging to other chemical group of compounds under study - benzilic acid amides.

Conclusions. The most active compounds under research appeared to be KMS-49 and KMS-284 after their introduction the latent period of the first licking of the paw sole increased by 2.2 and 1.6 times, respectively; and the latent period of the first jump - by 2.8 and 2.5 times, respectively, compared to the control group at the significance level $p \leq 0.05$.

Key words: benzilic acid derivatives; analgesic activity; "hot plate" test

Н. М. Трищук, І. В. Кіреєв, С. В. Колісник, К. М. Ситнік

Дослідження впливу похідних бензилової кислоти на поріг больової чутливості за допомогою тесту «гарячої пластини»

Пошук нових високоефективних аналгетиків є актуальною проблемою сучасної фрармакології, оскільки використовувані нині в клінічній практиці препарати не завжди відповідають вимогам ефективності та безпеки.

Мета роботи - дослідження впливу нових похідних бензилової кислоти на поріг больової чутливості за допомогою тесту «гарячої пластини».

Матеріали та методи. Об'єктами дослідження стали нові похідні бензилової кислоти. Визначення порогу больової чутливості проводили за допомогою тесту «гаряча пластина». Досліджувані речовини вводили перорально у вигляді водних розчинів у дозі 12 мг/кг. Під час дослідження реєстрували латентний час першого облизування підошви лап та латентний час першого стрибка.

Результати та їх обговорення. Шести- та семичленні тієнолактами не виявили аналгетичної активності, вихідні аміди бензилової кислоти значно перевищували їх за активністю, отже утворення циклічних продуктів призводило до зменшення активності. Введення до молекули атома хлору також призводило до зменшення активності. У той же час ефективною виявилась структурна модифікація амідного угруповання у складі тієнопіролів. В експерименті найактивнішою виявилась субстанція KMS-49, яка містить у своєму складі диметилацетильну групу. Іншою активною сполукою виявилось похідне KMS-284, яке належить до іншої хімічної групи досліджуваних сполук - амідів бензилової кислоти.

Висновки. Найактивнішими з досліджених речовин виявились KMS-49 та KMS-284, при введенні яких збільшувався латентний період першого облизування лапи в 2,2 і 1,6 рази, відповідно; та латентний період першого стрибка в 2,8 та 2,5 рази, відповідно, у порівнянні з групою контролю при рівні значущості $p \leq 0,05$.

Ключові слова: похідні бензилової кислоти; аналгетична активність; тест «гаряча пластина»

Н. М. Трищук, И. В. Киреев, С. В. Колесник, К. М. Сытник

\section{Исследование влияния производных бензиловой кислоты на порог болевой чувствительности с помощью теста «горячей пластины»}

Поиск новых высокоэффективных анальгетиков является актуальной проблемой современной фармакологии, поскольку используемые в настоящее время в клинической практике препараты не отвечают требованиям эфффективности и безопасности.

Цель работы - исследование влияния новых производных бензиловой кислоты на порог болевой чувствительности с помощью теста «горячей пластины». 
Материалы и методы. Объектами исследования стали новые производные бензиловой кислоты. Определение порога болевой чувствительности проводили с помощью теста «горячая пластина». Исследуемые вещества вводили перорально в виде водных растворов в дозе 12 мг/кг. В ходе исследования регистрировали латентное время первого облизывания подошвы лап и латентное время первого прыжка.

Результаты и их обсуждение. Шести- и семичленные тиенолактамы не проявили анальгетической активности, исходные амиды бензиловой кислоты значительно превышали их по активности, следовательно, образование циклических продуктов приводит к уменьшению активности. Введение в молекулы атома хлора также приводило к уменьшению активности. В то же время эффективной оказалась структурная модификация амидной группировки в составе тиенопирролов. В эксперименте самой активной оказалась субстанция KMS-49, которая содержит в своем составе диметилацетильную группу. Другим активным соединением оказалось производное KMS-284, которое относится к иной химической группе исследуемых соединений - амидам бензиловой кислоты.

Выводы. Наиболее активными из исследованных веществ оказались KMS-49 и KMS-284, при введении которых увеличивался латентный период первого облизывания лапы в 2,2 и 1,6 раза, соответственно; и латентный период первого прыжка в 2,8 и 2,5 раза, соответственно, по сравнению с группой контроля при уровне значимости $\mathrm{p} \leq 0,05$.

Ключевые слова: производные бензиловой кислоты; анальгетическая активность; тест «горячая пластина»

Determination of the body pain threshold is an essential part of biomedical, physiological and psychophysiological studies. Indicators of the pain threshold depend on the immune status, emotional state, stress factors and the degree of adaptation to it. Determination of the pain threshold is important for the study of efficacy of drugs with the analgesic action.

The search for new highly effective analgesics is a topical issue of modern pharmacology since drugs currently used in clinical practice do not meet the requirements of efficiency and safety. Narcotic analgesics are characterized by a strong analgesic effect, providing the possibility of their use for injuries and diseases accompanied by pain. However, they also affect the central nervous system: the first use cause euphoria, and further there is addiction and dependence $[1,2]$.

To determine the pain threshold the studies on laboratory animals are conducted using the "hot plate" test. This test is based on behavioral reactions controlled by supraspinal structures in response to the painful effect. After placing the animals on a hot surface when reaching the pain threshold there are motor anxiety reactions: withdrawal of paws, paw sole licking, jumping characterized by the most complex organization of reflex involving cortical and subcortical brain structures [3].

The aim of our work was to study the effect of new derivatives of benzilic acid on the pain threshold using the "hot plate" test.

\section{Materials and methods}

The objects of the study were new derivatives of benzilic acid synthesized at the Department of Organic Chemistry of National University of Pharmacy.

The substances studied were introduced orally as aqueous solutions in the dose of $12 \mathrm{mg} / \mathrm{kg}$. The control animals received the corresponding volume of saline. Animals were kept in the vivarium under standard conditions on a regular diet and with free access to water.

Determination of the pain threshold was carried out using the "hot plate" test. Laboratory animals were placed in chambers with the size of $200 \times 200 \times 300 \mathrm{~mm}$, which floor was heated to the temperature of $54-55^{\circ} \mathrm{C}$. The la- tent time of the first licking of the paw sole and latent time of the first jump were recorded during the study $[3,4]$.

The statistical analysis of the results was performed using the parametric Student t-test. The difference was considered to be significant at $\mathrm{p}<0.05$.

\section{Results and discussion}

The results of the effect of the benzyl acid derivatives studied on the pain threshold in laboratory animals are shown in Tab.

According to the results concerning the effect of the benzilic acid derivatives studied on physical endurance of the experimental animals introduction of KMS-303, KMS-258, KMS-230 and KMS-71 led to a decrease of the latent period of the first licking of the paw sole with significant changes observed in the groups of animals

Table

The effect of the benzilic acid derivatives studied on the pain threshold in laboratory animals

\begin{tabular}{|l|c|c|}
\hline Substance & $\begin{array}{c}\text { The latent period of } \\
\text { the first licking } \\
\text { of the paw sole, sec }\end{array}$ & $\begin{array}{c}\text { The latent period } \\
\text { of the first jump, sec }\end{array}$ \\
\hline Control & $9.8 \pm 1.3$ & $15.8 \pm 2.4$ \\
\hline KMS-49 & $21.4 \pm 2.3^{*}$ & $43.8 \pm 2.6^{*}$ \\
\hline KMS-69 & $12.8 \pm 1.9^{*}$ & $30.4 \pm 1.1^{*}$ \\
\hline KMS-228 & $13.6 \pm 1.1^{*}$ & $29.0 \pm 1.6^{*}$ \\
\hline KMS-230 & $8.4 \pm 1.1$ & $22.8 \pm 1.9^{*}$ \\
\hline KMS-71 & $8.2 \pm 1.3$ & $17.2 \pm 2.6$ \\
\hline KMS-284 & $16.0 \pm 1.6^{*}$ & $39.8 \pm 1.5^{*}$ \\
\hline KMS-303 & $6.6 \pm 1.1^{*}$ & $13.2 \pm 2.6$ \\
\hline KMS-258 & $4.6 \pm 1.5^{*}$ & $13.2 \pm 1.6$ \\
\hline KMS-68 & $12.8 \pm 2.6^{*}$ & $22.6 \pm 1.7^{*}$ \\
\hline KMS-73 & $14.0 \pm 2.9^{*}$ & $18.8 \pm 2.2$ \\
\hline KMS-229 & $10.0 \pm 0.7$ & $21.2 \pm 1.3^{*}$ \\
\hline KMS-282 & $11.2 \pm 1.9$ & $17.4 \pm 1.1$ \\
\hline
\end{tabular}

Note: ${ }^{*}-p \leq 0.05$ (vs. control animals). 


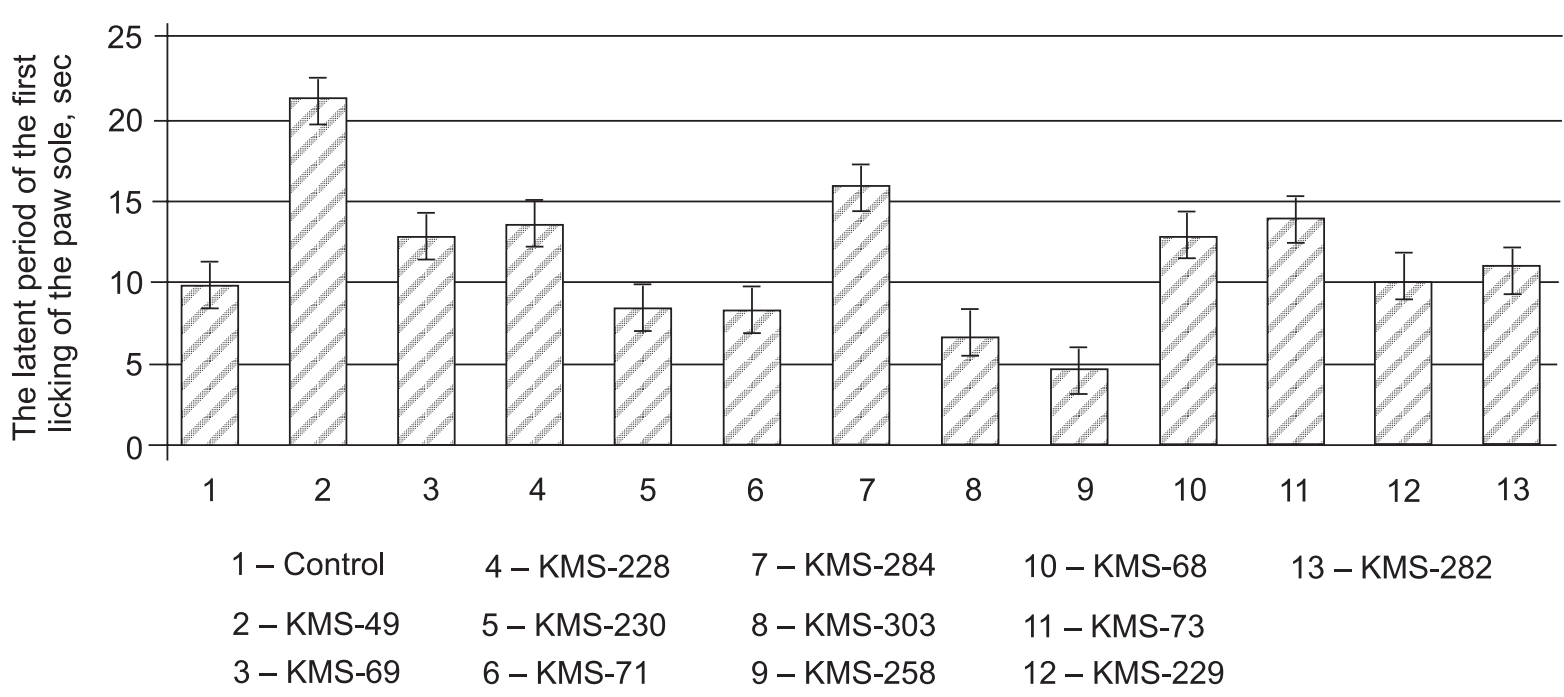

Fig. 1. The effect of the substances studied on the latent period of the first licking of the paw sole $\left({ }^{*}-p \leq 0.05\right.$ vs. control animals)

injected with KMS 303 and KMS-258 compared to the group of control animals (Fig. 1). After introduction of KMS-229 KMS-282 the pain threshold remained at the same level compared to the control group. A significant increase of physical endurance revealing in the extension of the latent period of the first licking of the paw sole was observed in the groups of animals after introduction of KMS-69, KMS-68, KMS-228, KMS-73, KMS-284 and KMS-49. The most active substance was KMS-49, which introduction led to an increase of the pain threshold in the experimental mice by 2.2 times compared to the control group of animals.

The second parameter studied was the latent period of the first jump (Fig. 2). Similarly, as in the previous experiment, introduction of KMS-303 and KMS-258 resulted in a decrease of the latent period of the first jump compared to the group of control animals, and introduction of KMS-71, KMS-282 and KMS-73 did not significantly affect this parameter. The rest of the substances studied increased the latent period of the first jump. Notably that the most active substances were KMS- 49 and KMS-284.

In the experiment several compounds - benzilic acid amides (KMS-228, KMS-230, KMS-282, KMS-283, KMS-284), products of its cyclization: KMS-229, KMS-258, KMS-303 and six- and seven-membered thienolactames and five-membered thienolactames with the functionalized amide function (KMS-49, KMS-68, KMS-69, KMS-71, KMS-73) were studied. Six- and seven-membered thienolactames did not show the analgesic activity (at the level of the control group), and acid benzilic ami des yielded far exceeded their activity. Hence, formation of cyclic products led to a decrease of the activity. Introduction of the chlorine atom into molecules also led to the decrease of activity (such compounds in pairs: KMS-228 - KMS-230 and KMS-229 - KMS-258). At the same time, the structural modification of the amide group in thienopyrroles was effective. In the experiment

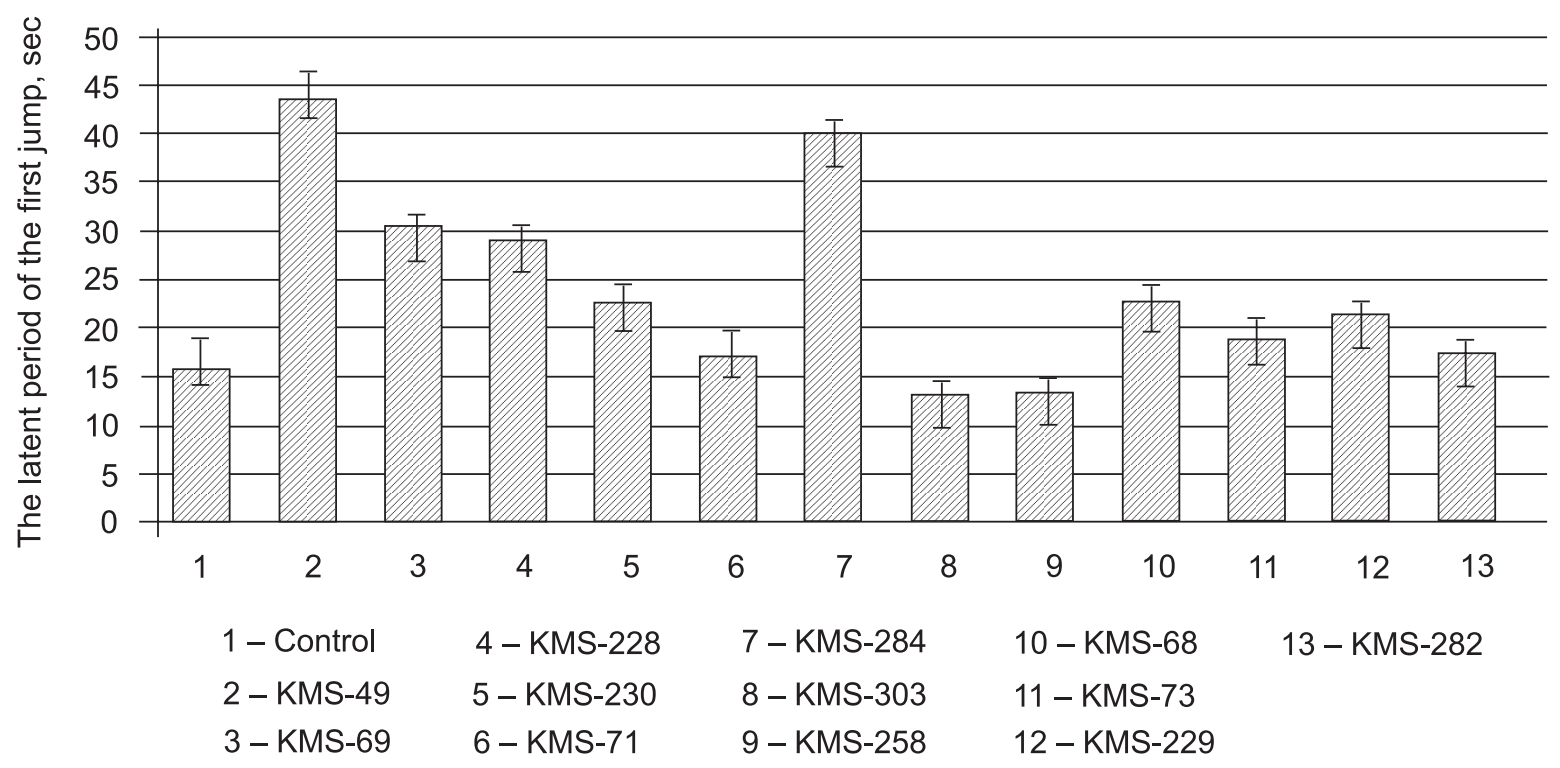

Fig. 2. The effect of the substances studied on the latent period of the first jump ( ${ }^{*}-p \leq 0.05$ vs. control animals) 
the most active substance was KMS-49 containing the dimethylacetyl group. Probably in the body this group is able to transform into the aldehyde or carboxyl group effectively binding to the active sites of enzymes. Another active compound was a derivative of KMS-284 belonging to other chemical group of compounds under study - benzilic acid amides. In the molecule of this compound there is 3-(5-methoxyindolil), which is a known pharmacophore with the pronounced effects on the CNS. Therefore, further search for effective substances with the central analgesic effect among derivatives of benzilic acid and functionalized derivatives of 6-oxo-4,4-
diphenyl-5,6-dihidro-4H-thieno[3,4-c]pyrrole-1-carboxylic acid is promising.

\section{CONCLUSIONS}

The most active compounds under research appeared to be KMS-49 and KMS-284 after their introduction the latent period of the first licking of the paw sole increased by 2.2 and 1.6 times, respectively; and the latent period of the first jump - by 2.8 and 2.5 times, respectively, compared to the control group at the significance level $\mathrm{p} \leq 0.05$.

Conflict of Interests: authors have no conflict of interests to declare.

\section{REFERENCES}

1. Анальгетические свойства бензимидазола / Т. В. Гамма, И. И. Корнелюк, Д. Р. Хусаинов и др. // Ученые записки Таврического нац. ун-та им. В. И. Вернадского. Серия «Биология, химия». - 2010. - Т. 23 (62), № 2. - С. 66-71.

2. Яковчук, Т. В. Антиноцицептивная активность солей салициловой и ацетилсалициловых кислот / Т. В. Яковчук // Прорывные научные исследования как двигатель науки : сб. статей междунар. науч.-практ. конф., г. Самара, 15 дек. 2015 г. - Ч. 3. - Самара : АЭТЕРНА, 2015. - C. 61-64.

3. Экспериментальное исследование анальгетической активности экстракта аконита Кузнецова / С. Г. Крылова, П. С. Зориков, Е. П. Зуева и др. // Тихоокеанский мед. журн. - 2014. - № 2. - С. 38-40.

4. NGF effects on hot plate behaviors in mice / Daniele Della Seta et al. // Pharmocol. Biochem. and Behavior. - 1994. - Vol. 49, Issue 3. - P. 701-705. doi: 10.1016/0091-3057(94)90090-6

\section{REFERENCES}

1. Gamma, T. V., Korneliuk, I. I., Khusainov, D. R. et al. (2010). Uchenye zapiski Tavricheskogo natcionalnogo universiteta im. V. I. Vernadskogo. Seriia «Biologiia, Khimiia»23 (62 (2)), 66-71.

2. Yakovchuk, T. V. (2015). Proryvnye nauchnye issledovaniia kak dvigatel nauki. Samara: AERTERNA, 61-64.

3. Krylova, S. G., Zorikov, P. S., Zueva, E. P. et al. (2014). Tikhookeanskii meditcinskii zhurnal, 2, 38-40

4. Della Seta, D., de Acetis, L., Aloe, L., Alleva, E. (1994). NGF effects on hot plate behaviors in mice. Pharmacology Biochemistry and Behavior, 49 (3), 701-705. doi: 10.1016/0091-3057(94)90090-6

\section{Information about authors:}

Tryschuk N. M., Candidate of Medicine (Ph.D.), associate professor of the Department of Pharmacotherapy, National University of Pharmacy

Kireyev I. V., Doctor of Medicine (Dr. habil.), head of the Department of Pharmacotherapy, National University of Pharmacy. E-mail: ivkireev@ukr.net

Kolisnyk S. V., Doctor of Pharmacy (Dr. habil.), professor of the Analytical Chemistry Department, National University of Pharmacy

Sytnik K. M., Candidate of Pharmacy (Ph.D.), associate professor of the Organic Chemistry Department, National University of Pharmacy

Відомості про авторів:

Трищук Н. М., канд. мед. наук, доцент кафедри фармакотерапії, Національний фармацевтичний університет

Кіреєв I. В., д-р мед. наук, професор, завідувач кафедри фармакотерапії, Національний фармацевтичний університет. E-mail: ivkireev@ukr.net.

Колісник С. В., д-р фармац. наук, професор кафедри аналітичної хімії, Національний фармацевтичний університет

Ситнік К. М., канд. фармац. наук, доцент кафедри органічної хімії, Національний фармацевтичний університет

Сведения об авторах:

Трищук Н. М., канд. мед. наук, доцент кафедры фармакотерапии, Национальный фармацевтический университет

Киреев И. В., д-р мед. наук, профессор, заведующий кафедры фармакотерапии, Национальный фармацевтический университет. E-mail: ivkireev@ukr.net

Колесник С. В., д-р фармац. наук, профессор кафедры аналитической химии, Национальный фармацевтический университет

Сытник К. М., канд. фармац. наук, доцент кафедры органической химии, Национальный фармацевтический университет 